\title{
THE TERRITORIAL CHARACTERISTICS OF EUROPEAN UNION SUBSIDIES FOR ECONOMIC DEVELOPMENT USED BY LOCAL AUTHORITIES IN THE ÉSZAK-ALFÖLD (NORTH GREAT PLAINS) REGION OF HUNGARY BETWEEN 2014 AND 2020
}

\author{
Zoltån BADAR \\ County Directorates of Hajdú-Bihar, Hungarian State Treasury, Hatvan utca 15., 4026 Debrecen, \\ Hungary, e-mail: badzol1990@gmail.com
}

\section{Gábor KOZMA *}

University of Debrecen, Faculty of Science and Technology, Institute of Earth Sciences, Department of Social Geography and Regional Development Planning, Egyetem tér 1., 4032 Debrecen, Hungary, e-mail: kozma.gabor@science.unideb.hu

Citation: Badar, Z., \& Kozma, G. (2020). The Territorial Characteristics of European Union Subsidies for Economic Development Used by Local Authorities in the Eszak-Alföld (North Great Plains) Region of Hungary between 2014 and 2020. Revista Română de Geografie Politică, 22(2), 48-60. https://doi.org/10.30892/rrgp.222101-336

\begin{abstract}
In the EU budgetary period 2014-2020 the Hungarian Government devoted significant attention to economic development and its plan was to use $60 \%$ of EU regional policy subsidy for this purpose. In the light of this fact, the main aim of our publication is examine the spatial characteristics of the EU economic development aid awarded to local authorities situated in North Great Plain Region (Hajdú-Bihar county, Jász-Nagykun-Szolnok county, SzabolcsSzatmár-Bereg county), and to point out the differences between the individual areas and settlements. As a result of our research it can be concluded that firstly the smallest settlements were in an unfavourable position (fewer subsidy applications and smaller subsidy amounts), while in case of larger settlements, the examination does not show clear results. Secondly, if we look at administrative functions of settlements, the favourable position of district seats can be observed, which is particularly true in case of the development of industrial parks and industrial areas subsidy topic, Thirdly, examining the socio-economic conditions of settlements, the more unfavourable position of less developed settlements can be observed (lower success rate of subsidy applications), and this was also true for all topics of subsidies.
\end{abstract}

Key words: European Union, cohesion policy, North Great Plains - Hungary, economic development

\footnotetext{
${ }^{*}$ Corresponding Author
} 


\section{INTRODUCTION}

After the accession of Central European countries to the European Union, one of the most important objectives was to facilitate the convergence of the region in terms of economic development, in which an important role was intended to be given to funds arriving in the framework of regional policy. The weight of the amounts concerned is well reflected by the fact that a very large proportion of investments in Hungary recently were implemented with the help of EU funding.

At the same time, in the period between 2014 and 2020, a major change occurred in the use of the approximately $€ 22$ billion of EU funds awarded to Hungary in comparison with the previous programming period: the Hungarian government has devoted very significant attention to economic development, and has declared its intention to use $60 \%$ of the given amount for this purpose. In the light of the above, in my opinion, it is a very important task to examine the general and territorial characteristics of the use of such funding as linked to local authorities in the specific region in Hungary, namely in the Észak-Alföld (North Great Plains) region, which is one of the least developed regions of the European Union.

The present paper consists of four larger units. After theoretical review the second unit presents the position of Hungary in the regional policy of the European Union between 2014 and 2020, while the third one deals with the situation of the region concerned and with the economic development concepts formulated in the counties constituting the region. What can be considered as the most important part of this paper is the fourth unit, which explores the spatial characteristics of the economic development aid received, pointing out the differences between the individual areas and settlements.

\section{THEORETICAL REVIEW}

The territorial analyses related to the European Union can be fundamentally divided into two groups. On the one hand, such studies examined the characteristics in the territorial distribution of subsidies, and in the course of this, they pointed out, among other things, the contradictions between the Cohesion Policy and national regional policies (Novosak et al., 2015), as well as the role of subsidies in the renewal of cities (Monyók and Kozma, 2017). Analyses on the Czech Republic (e.g. Smékalova, 2018) explored settlement hierarchy playing a stronger role than socio-economic development, while Polish research projects (Kisiala et al., 2017) have concluded that there is a balance between the even and the concentrated distribution of subsidies, with a slow shift towards the latter.

On the other hand, the researchers also examined the effect of the subsidies awarded on the given area. In the course of this they (e.g. Dall'Erba Le Gallo, 2007; Di Cataldo, 2017) showed, among other things, that the subsidies contributed to the economic growth of the less developed areas (at the same time, this effect was the strongest in the suburban areas near the cities Gagliardi and Percoco, 2017), to the reduction of regional disparities (but this effect revers above some level of transfer intensity - Kyriacou and Roca-Salagés, 2012), to the improvement of accessibility (although in certain cases, this could only be observed in international terms - Rosik et al., 2015), and also increased the R\&D performance of the given area (Ferrara et al., 2017). At the same time, the researchers have also pointed out that care must be exercised in the 
awarding of the European Union subsidies, and that certain problems may also arise. Medeiros (2014), for example, called attention to the fact that the lack of territorial planning and strategic vision deteriorates the efficient use of the funds; Becker et al., (2012) concluded that in $36 \%$ of the receiving regions the amount of the subsidies exceeded the amount that could be used efficiently, while Percoco (2017) warned about the importance of the economic structure of the given area (cohesion policy could exercise the biggest impact in regions having a weak service sector).

\section{DATA AND METHODS}

In the course of the preparation of the paper, we fundamentally used two types of methods. On the one hand, we analysed the development documents prepared in the given period for Hungary and the counties concerned, and relying on these documents, we strove to determine what the most important efforts were. On the other hand, using the results of the applications for EU funding from the palyazat.gov.hu portal, we examined the application activity of the local authorities in the counties concerned as well as their success rates, and comparing these results against the socio-economic data of the given region, attempted to draw conclusions.

\section{HUNGARY IN THE REGIONAL POLICY OF THE EUROPEAN UNION BETWEEN 2014 AND 2020}

In the period between 2014 and 2020, calculated at the actual prices, Hungary receives European Structural and Investment Funds (European Regional Development Fund, European Social Fund, Cohesion Fund, European Agricultural Fund for Rural Development, European Maritime and Fisheries Fund) in the amount of $€ 21.9$ billion. Pursuant to the Partnership Agreement concluded between the European Union and Hungary, the overall national development objective of the 2014-2020 programming period is economic growth based on sustainable production with high added value and increasing the employment rate. There are five priorities linked to the above national development objective, which cover the entirety of development policy:

1. Improving the competitiveness and global performance of the business sector

2. Promoting employment through economic development, employment, education and social inclusion policies, taking account territorial disparities

3. Enhancing energy and resource efficiency

4. Tackling social inclusion and demographic challenges

5. Implementation of local and territorial development aimed at promoting economic growth

The objective and the priorities are achieved via 9 operational programmes (OP-s), in the framework of which different amounts are available (table 1). The Hungarian government intends to use approximately $60 \%$ of the available funding for direct economic development, in the light of which it is not surprising that the largest share of the funding will be available to applicants by way of the Economic Development and Innovation Operational Programme. The shares of five operational programmes are very similar, while the role of the other three can be regarded as minimal. 
Table 1. The operational programmes drawn up by Hungary for the period between 2014 and 2020, and the related financial resources (\%)

(Data source: Hungarian Government, 2014a)

\begin{tabular}{|c|c|}
\hline Operational Programmes & $\begin{array}{c}\text { the proportion of the amount available in the } \\
\text { framework of the given operational programme } \\
\text { from the total funding for Hungary (\%) }\end{array}$ \\
\hline Human Resources Development OP & 10.4 \\
\hline $\begin{array}{c}\text { Economic Development and } \\
\text { Innovation OP }\end{array}$ & 30.9 \\
\hline $\begin{array}{c}\text { Integrated Transport OP } \\
\text { Enfficiency OP }\end{array}$ & 13.3 \\
\hline $\begin{array}{c}\text { Public Administration and Civil } \\
\text { Service OP }\end{array}$ & 12.8 \\
\hline OP Fisheries & 3.2 \\
\hline $\begin{array}{c}\text { Territorial and settlement } \\
\text { development OP }\end{array}$ & 0.2 \\
\hline Competitive Central Hungary OP & 13.5 \\
\hline Rural Development Programme & 1.9 \\
\hline
\end{tabular}

From the point of view of local authorities, the Territorial and and settlement development Operational Programme (TOP) has outstanding significance, the primary aim of which is to support investments arising on the local (primarily settlement) level, considered as important by the local authorities and implemented by them. Within the operational programme, 7 priority axes have been identified (table 2), most of which received funding from both the European Regional Development Fund and from the European Social Fund.

Table 2. The priority axes identified within the Territorial and settlement development

Operational Programme

(Data source: Hungarian Government, 2014b)

\begin{tabular}{|l|c|}
\hline \multicolumn{1}{|c|}{ Priority axes } & Share of priority axes (\%) \\
\hline $\begin{array}{l}\text { 1. Developing a regional economic environment to } \\
\text { promote employment }\end{array}$ & 24.2 \\
\hline $\begin{array}{l}\text { 2. Business-friendly, population-retaining } \\
\text { settlement development }\end{array}$ & 12.0 \\
\hline $\begin{array}{l}\text { 3. Transition to a low-carbon economy, particularly } \\
\text { for urban areas }\end{array}$ & 5.0 \\
\hline $\begin{array}{l}\text { 4. Development of local community services and } \\
\text { strengthen social cooperation }\end{array}$ & 7.3 \\
\hline $\begin{array}{l}\text { 5. County and local level human resource } \\
\text { development, social co-operation and employment } \\
\text { incentives }\end{array}$ & 31.4 \\
\hline $\begin{array}{l}\text { 6. Sustainable urban development in county-level } \\
\text { cities }\end{array}$ & 3.7 \\
\hline 7. Community-led local development & \\
\hline
\end{tabular}

Within the operational programme, a special situation was occupied by the "Sustainable urban development in county-level cities," behind the separate treatment of which we can find the objective that the given settlement (county seats and other towns and cities with populations of over 50,000 people) and other settlements should not compete with each other for the development funds 
(in the spirit of the above, the current analysis did not cover the three county seats in the region, and we also subtracted the population of the county seats from the population of the counties when calculating the relative values). In a separate decree, the government determined the amounts of development sources that would be available for the counties and cities of county rank [Government Decision no. 1702/2014. (XII. 3.)], and the leaders of the individual territorial units (county and municipal assemblies) decided how much they would allocate to each of the priority axes.

\section{THE PRESENTATION OF THE REGION EXAMINED}

Észak-Alföld, which is the region constituting the subject of our analysis, is located in the north-eastern part of Hungary, and it consists of three counties (Hajdú-Bihar county, Jász-Nagykun-Szolnok county, Szabolcs-Szatmár-Bereg county - figure 1). It is among the least developed regions of the European Union based on several criteria. On the one hand, the per capita GDP in the region was only $43 \%$ of the EU's average in 2017, which put it ahead of only seven NUTS 2 level regions in the EU. On the other hand, according to the EU's European Regional Competitiveness Index, it occupied the $233^{\text {rd }}$ position out of 268 regions, while on the basis of the European Regional Innovation Scoreboard, it was the $210^{\text {th }}$ out of 238 regions. In the light of the above, it is hardly surprising that the counties constituting the region had very high hopes in connection with the regional policy funds available in the 2014-2020 EU programming period, and trusted that with the help of these they would be able to reduce their disadvantages in development.

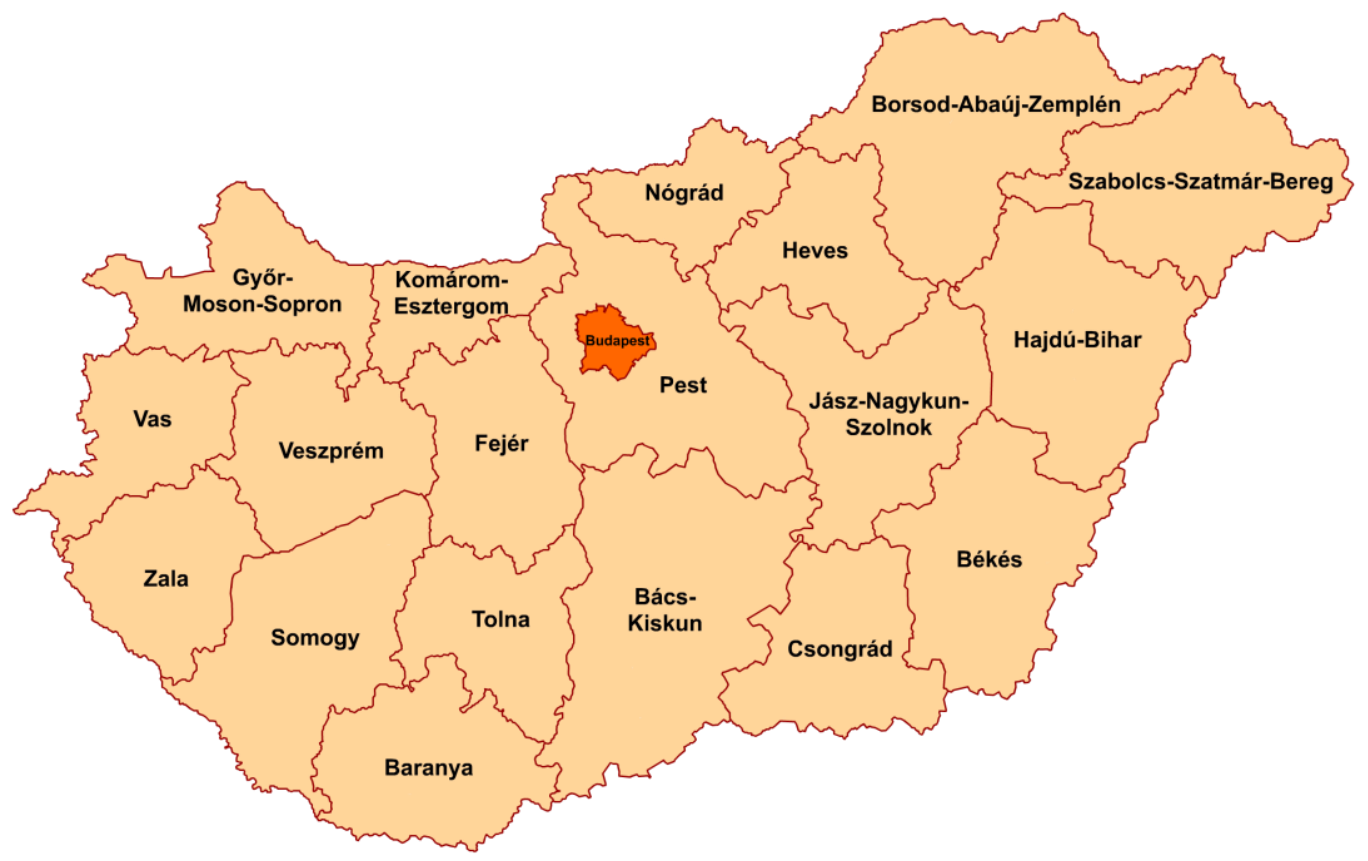

Figure 1. Location of three counties making up North Great Plains Region (Source: own work) 
Under the abovementioned Government decision no. 1702/2014. (XII. 3.), in the framework of the Territorial and settlement development Operational Program (TOP), together with national co-financing, Hajdú-Bihar county received HUF 49.62 billion, Jász-Nagykun-Szolnok county HUF 53.78 billion, while Szabolcs-Szatmár-Bereg county HUF 89.28 billion in subsidies. In the interest of using these funds, also taking into consideration the requirements of the European Union, all three counties have prepared their own regional development concepts, regional development programmes, as well as the integrated territorial programmes including the distribution of the available resources. The set of objectives defined in the documents concerned devotes particular attention to local economic development: from among the comprehensive objectives formulated in the three counties, one in each county was directly, while the others were indirectly linked to the improvement of economic conditions (table 3).

Table 3. The general objectives formulated in the territorial development concepts of the three counties examined

(Data source: Regional development concepts of three counties)

\begin{tabular}{|c|c|c|c|}
\hline & $1^{\text {st }}$ General objective & $2^{\text {nd }}$ general objective & $3^{\text {rd }}$ general objective \\
\hline $\begin{array}{l}\text { Hajdú- } \\
\text { Bihar } \\
\text { county }\end{array}$ & $\begin{array}{c}\text { Economic } \\
\text { development based on } \\
\text { the natural features, } \\
\text { traditions and } \\
\text { research potential of } \\
\text { Hajdú-Bihar county, } \\
\text { which increases } \\
\text { employment and } \\
\text { strengthens the } \\
\text { function of the county } \\
\text { as the innovation } \\
\text { centre of Eastern } \\
\text { Hungary }\end{array}$ & $\begin{array}{l}\text { The strengthening of } \\
\text { service, public health } \\
\text { and administrative } \\
\text { functions necessary } \\
\text { for reducing poverty } \\
\text { and social exclusion } \\
\text { and increasing the } \\
\text { marketable skills of } \\
\text { the working-age } \\
\text { population }\end{array}$ & $\begin{array}{l}\text { Effective water and } \\
\text { energy management } \\
\text { and the establishment } \\
\text { and development of } \\
\text { the conditions for } \\
\text { sustainable } \\
\text { environmental } \\
\text { management in order } \\
\text { to reduce the negative } \\
\text { effects of climate } \\
\text { change in the Trans- } \\
\text { Tisza region }\end{array}$ \\
\hline $\begin{array}{l}\text { Jász- } \\
\text { Nagykun- } \\
\text { Szolnok } \\
\text { county }\end{array}$ & $\begin{array}{l}\text { A strong link with the } \\
\text { development axes of } \\
\text { the macroeconomy }\end{array}$ & $\begin{array}{l}\text { Dynamic balance of } \\
\text { diverse cultural } \\
\text { landscapes }\end{array}$ & $\begin{array}{c}\text { Healthy, well- } \\
\text { educated population, } \\
\text { cooperative society }\end{array}$ \\
\hline $\begin{array}{l}\text { Szabolcs- } \\
\text { Szatmár- } \\
\text { Bereg } \\
\text { county }\end{array}$ & $\begin{array}{l}\text { The active county: } \\
\text { value-creating } \\
\text { employment and } \\
\text { increased activity }\end{array}$ & $\begin{array}{l}\text { The county showing } \\
\text { solidarity: Ending } \\
\text { extreme poverty and } \\
\text { supporting } \\
\text { underdeveloped areas }\end{array}$ & $\begin{array}{c}\text { The attractive county: } \\
\text { Creating an attractive } \\
\text { natural, social, } \\
\text { cultural, and } \\
\text { economic } \\
\text { environment }\end{array}$ \\
\hline
\end{tabular}

\section{RESULTS}

Local authorities were best able to support the realization of the economic development concepts in the framework of the $1^{\text {st }}$ priority axe of the Territorial and settlement sevelopment Operational Programme, "Developing a regional economic environment to promote employment," in which four measures, and within the first one, three sub-measures have been defined (later on, these constituted the subsidy structures that were announced):

- TOP 1.1: Development of local economic infrastructure

- TOP 1.1.1: Development of industrial parks and industrial areas 
- TOP 1.1.2: Development of incubator houses

- TOP 1.1.3: Development of local economy (e.g. the development of municipally owned markets, developments in the area of agricultural logistics, developments serving the purpose of public catering);

- TOP 1.2: Sustainable tourism development from a social and environmental point of view;

- TOP 1.3: Transportation development serving the promotion of economic development and the mobility of the labour force;

- TOP 1.4: The improvement of employment and life quality through the development of family-friendly institutions and public services helping employment.

We examined the first two of the above four measures because, on the one hand, the implementation of TOP 1.3 was the task of Magyar Közút Zrt. (Hungarian Public Road Ltd), the company responsible for the operation and maintenance of public roads in Hungary, and on the other hand, TOP 1.4 is related to the topic of economic development only tangentially.

In the framework of the abovementioned integrated territorial programmes, the individual counties determined what amounts they would devote to each of the objectives. On the level of the measures, the distribution of the financing was determined by provisions of law (this is what the identical proportions are due to); the decisions on the level of the sub-measures, however, could be made by the counties themselves (table 4). It can be determined from the figures that HajdúBihar county mainly concentrated on the development of industrial parks and industrial areas (it is partly true for Jász-Nagykun-Szolnok county as well), while Szabolcs-Szatmár-Bereg county put local economic development in the focus.

Table 4. The distribution of the available TOP funds according to (sub)measures in the three counties of North Great Plains region between 2014 and 2020

(Data source: palyazat.gov.hu)

\begin{tabular}{|l|c|c|c|c|c|c|}
\hline \multicolumn{2}{|c|}{} & TOP 1.1. & TOP 1.1.1. & TOP 1.1.2. & TOP 1.1.3. & TOP 1.2 \\
\hline $\begin{array}{l}\text { Hajdú-Bihar } \\
\text { county }\end{array}$ & $\mathrm{A}$ & 7,105 & 6,181 & 213 & 711 & 4,432 \\
\cline { 2 - 7 } & $\mathrm{B}$ & 14.3 & 12.5 & 0.4 & 1.4 & 8.9 \\
\hline $\begin{array}{l}\text { Jász-Nagykun- } \\
\begin{array}{l}\text { Szolnok } \\
\text { county }\end{array}\end{array}$ & $\mathrm{A}$ & 7,701 & 5,701 & 1,000 & 1,000 & 4,800 \\
\cline { 2 - 7 } & $\mathrm{B}$ & 14.3 & 10.6 & 1.9 & 1.9 & 8.9 \\
\hline $\begin{array}{l}\text { Szabolcs- } \\
\begin{array}{l}\text { Szatmár- } \\
\text { Bereg county }\end{array}\end{array}$ & $\mathrm{A}$ & 12,782 & 5,113 & 1,278 & 6,391 & 7,974 \\
\cline { 2 - 7 } & $\mathrm{B}$ & 14.3 & 5.7 & 1.4 & 7.2 & 8.9 \\
\hline
\end{tabular}

A - absolute amount (million HUF), B - participation from the total TOP funds available to the county (\%)

If we examine the level of activity in submitting subsidy applications (table 5), the most popular topics were tourism development and local economic development. The third place was occupied by the development of industrial parks and industrial areas, while in the development of business incubators the local authorities had a fairly low level of activity. A comparison of the three counties shows that the highest level of activity could be observed in Jász-NagykunSzolnok county, which was particularly true in the case of the measure related to tourism. The second place belongs to Szabolcs-Szatmár-Bereg county (which actually occupied the first place in case of the TOP 1.1 measure), while the lowest level could be observed in case of Hajdú-Bihar county (although in case of the tourism development measure it was ahead of Szabolcs-Szatmár-Bereg county). 
Table 5. The number of applications submitted to TOP subsidies in the topic of economic development in the three counties of the Észak-Alföld region in the 2014-2020 programming period (number of applications; in brackets: the value of all subsidy applications per 100,000 population, calculated with the 1 January 2017 populations figures)

(Data source: palyazat.gov.hu)

\begin{tabular}{|l|c|c|c|c|c|c|}
\hline & $\begin{array}{c}\text { TOP- } \\
1.1 .1 .\end{array}$ & TOP-1.1.2. & TOP-1.1.3. & TOP-1.1. & TOP-1.2.1. & total \\
\hline $\begin{array}{l}\text { Hajdú-Bihar } \\
\text { county }\end{array}$ & 18 & 1 & 17 & 36 & 29 & 65 \\
$(5.4)$ & $(0.3)$ & $(5.2)$ & $(10.9)$ & $(8.8)$ & $(19.7)$ \\
\hline Jász-Nagykun- & 25 & 2 & 18 & 45 & 39 & 84 \\
Szolnok county & $(8.3)$ & $(0.7)$ & $(5.9)$ & $(14.9)$ & $(12.9)$ & $(27.8)$ \\
\hline $\begin{array}{l}\text { Szabolcs- } \\
\text { Szatmár-Bereg }\end{array}$ & 28 & 5 & 50 & 83 & 27 & 110 \\
county & $(6.3)$ & $(1.1)$ & $(11.3)$ & $(18.7)$ & $(6.1)$ & $(24.8)$ \\
\hline total & 71 & 8 & 85 & 164 & 95 & 259 \\
& $(6.6)$ & $(0.7)$ & $(7.9)$ & $(15.2)$ & $(8.9)$ & $(24.1)$ \\
\hline
\end{tabular}

If we examine the success rates of the subsidy applications (table 6), we can find similar values (around 70\%) in case of the development of industrial parks and industrial areas and local economic development, while the lowest figures (partly due to the higher level of activity in submitting applications for subsidies) were found in connection with tourism development.

Table 6. The success rate of applications submitted for TOP subsidies in the topic of economic development in the three counties of the Észak-Alföld region in the 2014-2020 programming period (successful applications/submitted applications)

(Data source: palyazat.gov.hu)

\begin{tabular}{|l|c|c|c|c|c|}
\hline & TOP-1.1.1. & TOP-1.1.2. & TOP-1.1.3. & TOP-1.2.1. & otal \\
\hline Hajdú-Bihar county & 83.3 & 100.0 & 58.8 & 44.8 & 60.0 \\
\hline $\begin{array}{l}\text { Jász-Nagykun- } \\
\text { Szolnok county }\end{array}$ & 72.0 & 100.0 & 66.7 & 71.8 & 71.4 \\
\hline $\begin{array}{l}\text { Szabolcs-Szatmár- } \\
\text { Bereg county }\end{array}$ & 57.1 & 40.0 & 74.0 & 44.4 & 60.9 \\
\hline total & 69.0 & 62.5 & 69.4 & 55.8 & 64.1 \\
\hline
\end{tabular}

Table 7. The distribution of winning applications for TOP subsidies in the topic of economic development as a subject of settlement size (calculated with the 1 January 2017 population's figures)

(Data source: palyazat.gov.hu, National Territorial Development and Spatial Planning Information System)

\begin{tabular}{|l|c|c|c|c|}
\hline & $\begin{array}{c}\text { less than } \\
2,000 \\
\text { inhabitants }\end{array}$ & $\begin{array}{c}2,000- \\
5,000 \\
\text { inhabitants }\end{array}$ & $\begin{array}{c}5,000- \\
10,000 \\
\text { inhabitants }\end{array}$ & $\begin{array}{c}\text { more than 10,000 } \\
\text { inhabitants }\end{array}$ \\
\hline $\begin{array}{l}\text { share in the } \\
\text { population of the } \\
\text { three counties (\%) }\end{array}$ & 22.5 & 25.6 & 21.4 & 30.5 \\
\hline $\begin{array}{l}\text { share in the winning } \\
\text { subsidy applications } \\
(\%)\end{array}$ & 20.2 & 32.5 & 22.1 & 25.8 \\
\hline $\begin{array}{l}\text { share in the funds } \\
\text { secured (\%) }\end{array}$ & 13.6 & 27.6 & 26.0 & 32.8 \\
\hline
\end{tabular}

When analysing the territorial characteristics of the applications (table 7), we placed the main emphasis on the settlements, in the framework of which the first criterion of examination was the size of the settlements. On the basis of the 
findings, first of all, the unfavourable position of settlements with a population below 2,000 persons can be observed: their share in both the winning applications and in the amount of the funds secured is lower than their share in the population of the region. In case of the next two population categories, the opposite is true (their share in the population is lower than the other two indicators), while in case of larger settlements, a transitory situation can be observed. The low share of settlements in the number of subsidy applications can be primarily attributed to the fact that the locally available capabilities (e.g. potential subsidy application opportunities, suitable management skills) allowed them to elaborate subsidy applications only to a limited extent.

With respect to the individual topics of the subsidies, however, very significant differences could be observed (table 8). In case of the development of industrial parks and industrial areas, the special position of larger settlements (more than 5,000 inhabitants) is quite clear; what is behind this fact is the preference of companies requiring such investments for larger settlements for a variety of reasons (e.g. the availability of suitable source of labour). By contrast, settlements with smaller populations played a much more important role in local economic development: the proportion of the two smallest categories was almost $1 / 3$ also in terms of the amounts of the subsidies awarded. This can be explained by the fact that in the framework of such subsidies the support for such investments was in the focus (e.g. the development of local markets) that also played an important role in the lives of smaller settlements.

In terms of the development of tourism, the special position of settlements with a population between 2,000 and 5,000, as well as the largest settlements could be observed. The success of such subsidy applications depends primarily on the individual characteristics of the given settlements, which are of course, on the one hand, richer than the larger settlements; on the other hand, however, the situation is not so clear in case of settlements with populations below 10,000 people.

Table 8. The distribution of winning applications for TOP subsidies in the topic of economic development as a function of settlement size and the subsidy topics (Data source: palyazat.gov.hu, National Territorial Development and Spatial Planning Information System)

\begin{tabular}{|l|l|c|c|c|c|}
\hline \multicolumn{2}{|c|}{} & $\begin{array}{c}\text { less than } \\
2,000 \\
\text { inhabitants }\end{array}$ & $\begin{array}{c}2,000- \\
5,000 \\
\text { inhabitants }\end{array}$ & $\begin{array}{c}5,000- \\
10,000 \\
\text { inhabitants }\end{array}$ & $\begin{array}{c}\text { more than } \\
10,000 \\
\text { inhabitants }\end{array}$ \\
\hline \begin{tabular}{l} 
share in the $\begin{array}{l}\text { shinning subsidy } \\
\text { applications (\%) }\end{array}$ \\
\cline { 2 - 6 }
\end{tabular} & TOP-1.1.1 & 6.1 & 26.5 & 36.7 & 30.6 \\
\cline { 2 - 6 } & TOP-1.1.3 & 33.9 & 40.7 & 6.8 & 18.6 \\
\hline $\begin{array}{l}\text { share in the } \\
\text { funds secured } \\
(\%)\end{array}$ & 19.6 & 29.4 & 23.5 & 27.5 \\
\cline { 2 - 6 } & TOP-1.1.1 & 3.6 & 25.6 & 36.6 & 34.2 \\
\cline { 2 - 6 } & TOP-1.1.3 & 32.5 & 32.6 & 10.8 & 24.1 \\
\hline
\end{tabular}

Several important conclusions can be drawn with respect to the average size of the projects realized (table 9). On the one hand, the subsidies of the highest amounts were characteristics in the topics of the development of industrial parks and industrial areas and in tourism development, while in case of local economic development, the amounts were much smaller. What is primarily in the background of the above is that investments in the former two 
groups included many expensive elements (e.g., in case of TOP-1.1.1, the construction of lineal infrastructure, while in case of TOP-1.2.1, the purchasing of the tourism-related visual elements), which increased the size of the investments. By contrast, in case of local economic development, it was fundamentally the upgrading of the existing elements (e.g. local market) that took place, which meant a lower level of cost demands.

On the other hand, taking all economic development subsidy applications into consideration, with the increase of the population, the size of the subsidy applications also generally increased; however, there were differences in terms of the various topics. The fact mentioned in the previous sentence is true for the development of industrial parks and industrial areas, which is primarily due to the larger settlements being in the focus of interests for more companies, which necessitates the formation of industrial properties of larger sizes. In case of the other two subsidy topics, however, this pattern could not be observed, and this is particularly true for local economic development subsidies. In our opinion, this is attributable to the fact that in this case it is decisively the local characteristics that determined the size of the developments concerned, and the role of the settlement size can be regarded as minimal.

Table 9. The average project size of winning applications for TOP subsidies in the topic of economic development as a function of settlement population size and the subsidy topics (million Ft) (Data source: palyazat.gov.hu, National Territorial Development and Spatial Planning Information System)

\begin{tabular}{|l|c|c|c|c|c|}
\hline & $\begin{array}{c}\text { less than } \\
2,000 \\
\text { inhabitants }\end{array}$ & $\begin{array}{c}2,000-5,000 \\
\text { inhabitants }\end{array}$ & $\begin{array}{c}5,000- \\
10,000 \\
\text { inhabitants }\end{array}$ & $\begin{array}{c}\text { more than } \\
10,000 \\
\text { inhabitants }\end{array}$ & total \\
\hline TOP-1.1.1 & 235.8 & 383.6 & 396.3 & 444.5 & 397.8 \\
\hline TOP-1.1.3 & 128.2 & 107.1 & 212.2 & 172.9 & 133.6 \\
\hline TOP-1.2.1 & 312.1 & 345.0 & 315.3 & 460.8 & 363.4 \\
\hline all of the topics & 193.7 & 245.7 & 340.5 & 368.8 & 289.3 \\
\hline
\end{tabular}

As regards the settlements, the next aspect examined was legal status, and in this respect, we analysed the potential preference toward district seats (table 10).

Table 10. The proportion of subsidy applications from district seats in proportion to all successful TOP subsidy applications in the topic of economic development in the three counties of the North Great Plains Region

(Data source: palyazat.gov.hu, National Territorial Development and Spatial Planning Information System)

\begin{tabular}{|l|c|c|c|c|}
\hline & $\begin{array}{c}\text { Hajdú-Bihar } \\
\text { county }\end{array}$ & $\begin{array}{c}\text { Jász-Nagykun- } \\
\text { Szolnok county }\end{array}$ & $\begin{array}{c}\text { Szabolcs- } \\
\text { Szatmár-Bereg } \\
\text { county }\end{array}$ & $\begin{array}{c}\text { North Great } \\
\text { Plains } \\
\text { Region }\end{array}$ \\
\hline $\begin{array}{l}\text { share in the } \\
\text { number of } \\
\text { inhabitants (\%) }\end{array}$ & 44.4 & 39.0 & 23.4 & 34.2 \\
\hline $\begin{array}{l}\text { share in the } \\
\text { winning subsidy } \\
\text { applications (\%) }\end{array}$ & 40.5 & 36.7 & 26.9 & 33.5 \\
\hline $\begin{array}{l}\text { share in the funds } \\
\text { secured (\%) }\end{array}$ & 59.2 & 46.5 & 47.7 & 49.8 \\
\hline
\end{tabular}

If we examine the region as a unit as opposed to county by county, we can immediately determine the significant share of the district seats from the subsidies secured (with indicators much higher than the other two), which refers 
to projects of larger scale on these settlements. Among the three counties, the biggest difference was found in Szabolcs-Szatmár-Bereg county, which is primarily due to its characteristic settlement structure: on the one hand, the proportion of district seats among settlements is the lowest here (approximately $5 \%$, as opposed to around $10 \%$ in the other two counties), which causes a low share of the settlements concerned in the population. On the other hand, the settlements outside of the district seats have very low population levels (their average number of inhabitants is 1,576 inhabitants/settlement in SzabolcsSzatmár-Bereg county, 2,516 inhabitants/settlement in Hajdú-Bihar county and 2,668 inhabitants/settlement in Jász-Nagykun-Szolnok county), which causes also low levels of activity in subsidy applications.

The result of the analysis between the administrative legal status of the settlements and the topics of the subsidy applications is fundamentally in line with the facts established above (table 11). The outstanding role of district seats can be observed primarily in case of the development of industrial parks and industrial areas, as well as in local economic development as topics. Investments in the former category have a significant force of spatial organisation, and consequently it is not surprising that such investments are realized on settlement of higher importance from an administrative point of view. Projects in the latter category primarily satisfy local needs, and thus, settlements outside of the district seats could also have opportunities.

Table 11. The distribution of winning applications for TOP subsidies in the topic of economic development as a function of administrative legal status of the settlements and the subsidy topics

(Data source: palyazat.gov.hu, National Territorial Development and Spatial Planning Information System)

\begin{tabular}{|l|l|c|c|}
\hline \multicolumn{2}{|l|}{} & district seats & other settlements \\
\hline share in the number of inhabitants (\%) & 34.2 & 65.8 \\
\hline \multirow{2}{*}{$\begin{array}{l}\text { share in the winning } \\
\text { subsidy applications }\end{array}$} & TOP-1.1.1 & 46.9 & 53.1 \\
\cline { 2 - 4 } & TOP-1.1.3 & 16.9 & 83.1 \\
\cline { 2 - 4 } & TOP-1.2.1 & 37.7 & 62.3 \\
\hline \multirow{2}{*}{$\begin{array}{l}\text { share in the funds } \\
\text { secured (\%) }\end{array}$} & TOP-1.1.1 & 60.3 & 39.7 \\
\cline { 2 - 4 } & TOP-1.1.3 & 25.0 & 75.0 \\
\cline { 2 - 4 } & TOP-1.2.1 & 48.8 & 51.2 \\
\hline
\end{tabular}

The last element of the examination of settlements was the analysis of the link between the socio-economic position and subsidy activities, in the course of which we used the beneficiary status calculated on the basis of several indicators and also recorded in a provision of law for the determination of the socio-economic position (105/2015. (IV. 23.) Government Regulation on the classification on beneficiary settlements). On the basis of the data it can be concluded (table 12) that decision-makers did not strive to improve the position of settlements having a weaker socio-economic standing by way of economic development subsidies: the share of such settlements relative to total population exceeds their share in the successful subsidy applications and in the total amount of subsidies awarded (especially this latter fact can be regarded as unfavourable).

The analysis of the individual subsidy topics (table 13), in almost all cases, reveals the unfavourable position of beneficiary settlements, with the proportion of successful subsidy applications in the TOP-1.1.3 topic being the 
sole exception. In terms of the amounts of subsidies awarded, the smallest difference (i.e. shortfall) is found in case of subsidies for tourism development, which can be regarded as an advantageous characteristic from the point of view that these generate new jobs as well as a revenue for the local authority, which may help the given settlement in closing the gap (it is from this point of view that the significant underrepresentation of subsidies for the development of industrial parks and industrial areas, which also has a similar effect, is an unfavourable characteristics).

Table 12. The proportion of subsidy applications from beneficiary settlements relative to all successful TOP subsidy applications in the topic of economic development in the three counties of the North Great Plains Region

(Data source: palyazat.gov.hu, 105/2015. (IV. 23.) Government Regulation)

\begin{tabular}{|l|c|c|c|c|}
\hline & $\begin{array}{c}\text { Hajdú-Bihar } \\
\text { county }\end{array}$ & $\begin{array}{c}\text { Jász-Nagykun- } \\
\text { Szolnok county }\end{array}$ & $\begin{array}{c}\text { Szabolcs- } \\
\text { Szatmár-Bereg } \\
\text { county }\end{array}$ & $\begin{array}{c}\text { North Great } \\
\text { Plains } \\
\text { Region }\end{array}$ \\
\hline $\begin{array}{l}\text { share in the } \\
\text { number of } \\
\text { inhabitants (\%) }\end{array}$ & 48.5 & 31.8 & 65.5 & 50.8 \\
\hline $\begin{array}{l}\text { share in the } \\
\text { winning subsidy } \\
\text { applications (\%) }\end{array}$ & 48.6 & 26.7 & 64.2 & 47.0 \\
\hline $\begin{array}{l}\text { share in the } \\
\text { funds secured } \\
\text { (\%) }\end{array}$ & 37.6 & 17.8 & 57.6 & 41.3 \\
\hline
\end{tabular}

Table 13. The distribution of winning applications for TOP subsidies in the topic of economic development as a function of the beneficiary status of the settlements and the subsidy topic

(Data source: palyazat.gov.hu, 105/2015. (IV. 23.) Government Regulation)

\begin{tabular}{|l|l|c|c|}
\hline \multicolumn{2}{|l|}{} & $\begin{array}{c}\text { beneficiary } \\
\text { settlements }\end{array}$ & other settlements \\
\hline share in the number of inhabitants (\%) & 50.8 & 49.2 \\
\hline \multirow{2}{*}{$\begin{array}{l}\text { share in the winning } \\
\text { subsidy applications }\end{array}$} & TOP-1.1.1 & 44.9 & 55.1 \\
\cline { 2 - 4 } & TOP-1.1.3 & 55.9 & 44.1 \\
\cline { 2 - 4 } & TOP-1.2.1 & 39.6 & 60.4 \\
\hline \multirow{2}{*}{$\begin{array}{l}\text { share in the funds } \\
\text { secured (\%) }\end{array}$} & TOP-1.1.1 & 41.6 & 58.4 \\
\cline { 2 - 4 } & TOP-1.1.3 & 46.3 & 53.7 \\
\cline { 2 - 4 } & TOP-1.2.1 & 48.0 & 52.0 \\
\hline
\end{tabular}

\section{CONCLUSION}

The most important findings of the study could be summarised as follows Even though the statutory frameworks determined the amounts of the subsidies available for the different purposes, within these frameworks, Hajdú-Bihar county primarily concentrated on the development of industrial parks and industrial areas, while Szabolcs-Szatmár-Bereg county put local economic development covering several areas into the foreground. Subsidies for tourism development were the most popular among the local authorities, and it is partly due to this popularity that the success rates were the lowest in case of this topic.

If we examine the influence that population size plays, we can find that the smallest settlements were in an unfavourable position (fewer subsidy applications and smaller subsidy amounts), while in case of larger settlements, 
the examination carried out from various points of view does not show clear results. In terms of the administrative position of settlements, the favourable position of district seats can be observed, which is particularly true in case of the development of industrial parks and industrial areas subsidy topic, which has a significant force of spatial organisation. In terms of the socio-economic conditions of settlements, the more unfavourable position of less developed settlements can be observed (lower success rate of subsidy applications), and this was also true for all topics of subsidies.

\section{REFERENCES}

Becker, S.O., Egger, P.H., \& Von Ehrlich, M. (2012). Too much of a good thing? On the growth effects of the EU's regional policy. European Economic Review, 56(4), 648-668.

Dall'Erba, S., \& Le Gallo, J. (2007). The impact of EU regional support on growth and employment. Czech Journal of Economics and Finance, 57(7), 325-340.

Di Cataldo, M. (2017). The impact of EU Objective 1 funds on regional development: Evidence from the UK and the prospect of Brexit. Journal of Regional Science, 57(5), 814-839.

Ferrara, A.R., McCann, P., Pellegrini, G., Stelder, D., \& Terribile, F. (2017). Assessing the impacts of Cohesion Policy on EU regions: A non-parametric analysis on interventions promoting research and innovation and transport accessibility. Papers in Regional Science, 96(4), 817-841.

Gagliardi, L., \& Percoco, M. (2017). The impact of European Cohesion Policy in urban and rural regions. Regional Studies, 51(6), 857-868.

Hungarian Government (2014a) Partnership Agreement for Hungary, 2014-2020. Budapest - Brussels.

Hungarian Goverment (2014b) Territorial and settlement development Operational Programme. Budapest.

Kisiała, W., Bajerski, A., \& Stępiński, B. (2017). Equalising or polarising: The centre-periphery model and the absorption of EU funds under regional operational programmes in Poland. Acta Oeconomica, 67(3), 413-434.

Kyriacou, A.P., \& Roca-Sagalés, O. (2012). The impact of EU structural funds on regional disparities within member states. Environment and Planning C: Government and Policy, 30(2), 267-281.

Medeiros, E. (2014). Assessing territorial impacts of the EU Cohesion Policy: The Portuguese case. European Planning Studies, 22(9), 1960-1988.

Monyók, B., \& Kozma, G. (2017). Developments funded by the European Union in the service of urban design in the North Great Plain Region (Hungary). Revista Română de Geografie Politică, 19(1), 13-23.

Novosak, J., Hajek, O., Smekalova, L., Nekolova, J., \& Skarka, M. (2015). Territorial cohesion and the geography of EU cohesion policy funding in the Czech Republic. Transformations in Business \& Economics, 14(3), 419-432.

Percoco, M. (2017). Impact of European Cohesion Policy on regional growth: does local economic structure matter?, Regional Studies, 51(6), 833-843,

Rosik, P., Stepniak, M., \& Komornicki, T. (2015). The decade of the big push to roads in Poland: Impact on improvement in accessibility and territorial cohesion from a policy perspective. Transport policy, 37, 134-146.

Smékalová, L. (2018). Evaluating the cohesion policy: targeting of disadvantaged municipalities. Revista Administratie si Management Public (RAMP), 31, 143-154.

Submitted:

March 21, 2020
Revised:

June 20, 2020
Accepted and published online: July 31, 2020 